\title{
HYDROXYAPATITE DEPOSITION ON THE LASER MODIFIED Ti13Nb13Zr ALLOY
}

\begin{abstract}
The Ti13Nb13Zr alloy was subjected to laser modification with the Nd:YAG laser provided that such treatment would increase the surface roughness followed improved adhesion of hydroxyapatite (HAp) coatings The hydroxyapatite was deposited by electrophoretic method in suspension of $0.5 \mathrm{~g}$ HA powder and $100 \mathrm{ml}$ ethyl alcohol. The deposition was carried out for $10 \mathrm{~min}$ at $10 \mathrm{~V}$ voltage followed by drying at room temperature for $24 \mathrm{~h}$ and heating at $800^{\circ} \mathrm{C}$ for $1 \mathrm{~h}$ in vacuum. The thickness of the HAp coatings was found as of about $4.06 \mu \mathrm{m}$ to $9.05 \mu \mathrm{m}$. The examinations of surfaces were carried out at each stage of the experiment with the ultra-high resolution scanning electron microscope. The measurements of surface roughness after laser treatment and after HAp deposition were performed with the Hommel Etamic Waveline profilograph.
\end{abstract}

Keywords: Ti13Nb13Zr alloy, laser treatment, hydroxyapatite, implants

\section{INTRODUCTION}

The titanium alloys are widely used as load-bearing dental and orthopaedic implants. The Ti13Nb13Zr alloy is more biocompatible then others because of non-toxicity elements $(\mathrm{Nb}$, $\mathrm{Zr}$ ) and relatively low Young's modulus [1]. The osseointegration of an implant and a bone is achieved the most often by surface deposition of hydroxyapatite (HAp) coatings [2]. The most popular deposition methods involve: plasma spraying [3], electrodeposition [4], CVD and PVD, sol-gel method and ion beam sputtering [5-7]. As those ceramic coatings are brittle, very thin coatings or nanocoatings are developed by the pulsed laser deposition (PLD) or electrophoretic techniques (EPD) [8-11].

The condition for proper implantation and later healing is mechanical after-surgery stability of an implant and development of real surface adjacent to the bone tissue. The final state of implant surface decides on biological activity of tissue in close neighbourhood of the implant [12]. So far examinations of surfaces of titanium implants for bone surgery have disclosed that osseointegration on rough surface is much faster than on smooth ones. Hence, the roughness of implant surface influences on adhesion of HAp coatings and components of biological environment.

As shown earlier [13], the most plausible roughness for an intensive response of bone tissue can be defined by $S_{a}$ value equal 1-2 $\mu \mathrm{m}$. The rougher surfaces enhance colonisation, proliferation and differentiation of osteoblasts so that promote bonding an implant to the bone 
tissue. The moderately rough surface is optimal because of perfect fitting to the connective and bone tissue $[13,14]$.

The research was aimed to determine the effect of surface roughness of the Ti13Nb13Zr alloy, modified by laser treatment, on structure and final roughness of the HAp coating obtained by electrophoretic deposition. The novelty in our research was an use of pulse laser as the continuous work laser would cause the appearance of surface cracks, as shown for the Ti6Al4V alloy $[15,16]$. It was assumed that by such precise laser treatment was assumed to it becomes possible to create micro and nanorough surface, and the thin HAp - to perfectly modelise the surface roughness enhancing the osseointegration of the implant and the tissue.

\section{EXPERIMENTAL}

The Ti13Nb13Zr alloy [17] was chosen among all Ti alloy because of the lowest Young's modulus (79 $\mathrm{GPa}$ ) reducing the possible screening effect of the stresses around the implant. Chemical composition of the Ti13Nb13Zr alloy is presented in Table 1.

Table 1. Chemical composition of the Ti13Nb13Zr alloy according to the producer's attestation

\begin{tabular}{|c|c|c|c|c|c|c|c|c|}
\hline \multicolumn{10}{|c|}{ Chemical composition [\% wt.] } \\
\hline $\mathrm{Nb}$ & $\mathrm{Zr}$ & $\mathrm{Fe}$ & $\mathrm{C}$ & $\mathrm{H}$ & $\mathrm{O}$ & $\mathrm{S}$ & $\mathrm{Hf}$ & $\mathrm{Ti}$ \\
\hline 13.18 & 13.49 & 0.085 & 0.035 & 0.004 & 0.078 & $<0.001$ & 0.055 & rest \\
\hline
\end{tabular}

The specimens of $4 \mathrm{~mm}$ in thickness were cut from rod of $30 \mathrm{~mm}$ in diameter. Specimens were subjected to surface treatment by the pulse laser Nd:YAG TruLaser Station 5004 (TRUMPF). The overlapping was 50\% for each pulse and each laser passage, before laser modification the samples after prior degreasing with acetone. The laser treatment was carried out in argon atmosphere. The parameters of laser treatment are presented in Table 2.

Table 2. Parameters of laser treatment of the Ti13Nb13Zr alloy

\begin{tabular}{|c|c|c|c|c|}
\hline Sample & $\begin{array}{c}\text { Power of the laser } \\
\text { pulse [W] }\end{array}$ & $\begin{array}{c}\text { Duration of the } \\
\text { laser pulse [ms] }\end{array}$ & $\begin{array}{c}\text { Linear speed } \\
{[\mathrm{mm} / \mathrm{min}]}\end{array}$ & $\begin{array}{c}\text { Frequency } \\
{[\mathrm{Hz}]}\end{array}$ \\
\hline LT 1 & 1000 & 2.33 & 660 & 46.4 \\
\hline LT 2 & 1100 & 4.45 & 480 & 24 \\
\hline
\end{tabular}

The deposition of HAp coatings was made by electrophoretic method. The specimens before deposition were rinsed with isopropanol, cleaned in distilled water for $30 \mathrm{~min}$ and pickled in $25 \% \mathrm{HNO}_{3}$ for $10 \mathrm{~min}$ and, at the end, rinsed with distilled water. The Pt electrode as an anode and the treated specimens and the base material, as a cathode were applied. The suspension for electrophoretic deposition was prepared from the HAp powder (made by 
Sigma) and ethyl alcohol, mixed in a ratio of $0.5 \mathrm{~g}$ HA to $100 \mathrm{ml}$ of alcohol in the ultrasound washer for $90 \mathrm{~min}$. The distance between electrodes was fixed at $30 \mathrm{~mm}$. The voltage of $10 \mathrm{~V}$, and deposition time of $10 \mathrm{~min}$ were applied. The experiment was repeated 3 times for each sample - LT 1, LT 2 and base material (BM). The deposited surfaces were air-dried for $24 \mathrm{~h}$. Afterwards they were thermally treated in a tubular furnace (PROTHERM PC442, Ankara, Turkey) at $800^{\circ} \mathrm{C}$ at a rate $100^{\circ} \mathrm{C} / \mathrm{h}$, then maintained for $1 \mathrm{~h}$ and slowly cooled down in a vacuum furnace.

The microstructures and cross-section HAp coatings were observed using an ultra high resolution Scanning Electron Microscope (SEM JEOL JSM- 6480). The chemical composition of the coatings was investigated by the X-ray energy dispersive spectrometer (EDS), Edax Inc., U.S.A. The phase analysis was performed with X-ray diffractometer pattern (XRD Philips X'Pert Pro, Netherlands) with monochromatized $\mathrm{Cu} \mathrm{K} \alpha$ radiation and a scan rate $0.02 \mathrm{~s}$ within the 2 range of 10 and 90 . The measurements of surface roughness after laser treatment and after HAp deposition were performed with the Hommel Etamic Waveline profilograph (JENOPTIK).

\section{RESULTS AND DISCUSSION}

View of the surface of laser modified alloy is shown in Fig. 1. The specimens presented change of colour after laser treatment, despite the use of protective gas during modification.
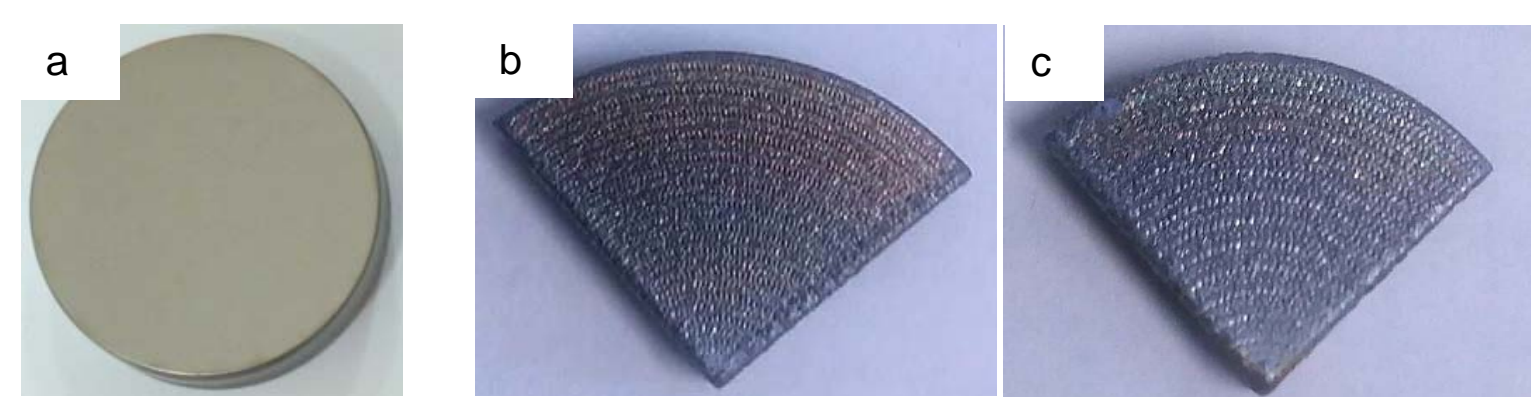

Fig. 1. Surface microstructure of the Ti13Nb13Zr alloy: a) before laser treatment and cut (BM) b) after laser treatment (LT 1), c) after laser treatment (LT 2)

Fig. 2. demonstrated microscopic surface of laser remelted $\mathrm{Ti} 13 \mathrm{Nb} 13 \mathrm{Zr}$ alloy. The continues layers and grain refinement are visible. Finer grain surface zone is characteristic of a laser treatment samples of parameter LT 1. 

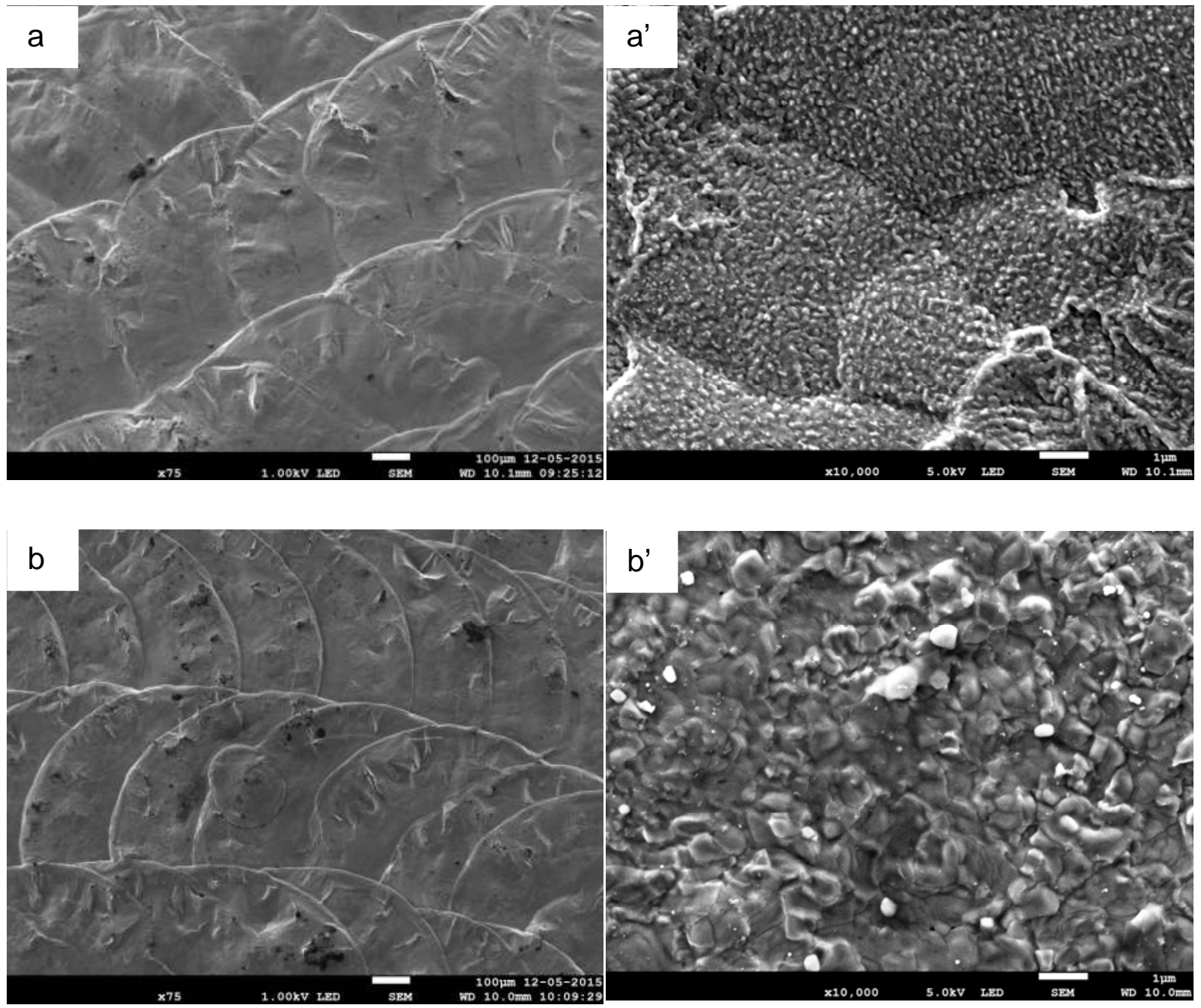

Fig. 2. Surface microstructure of the Ti13Nb13Zr after laser treatment: $a, a^{\prime}$ - LT 1, b, b' - LT 2

The surface appearance and topography of HAp coatings for specimens after laser modifications and base material are presented on Fig. 3. The electrophoretic process affect quality, thickness and crystallinity of obtained HAp coatings. The mostly continuous and lower grain HAp coatings were obtained specimen for HC 2. The obtained coatings possess small grain structure.

Averaged results and standard division for three measurements of roughness are shown in Table 3. The obtained results indicate that the laser treatment increase the surface roughness as the parameter $R_{a}$ increases with increasing power of laser. The electrophoretic deposition of HAp coatings slighty increases the surface roughness. Such surface roughness in an evidence of surface development (the increase in real surface area) what would result in better adhesion of osteoblasts $[18,19]$. 

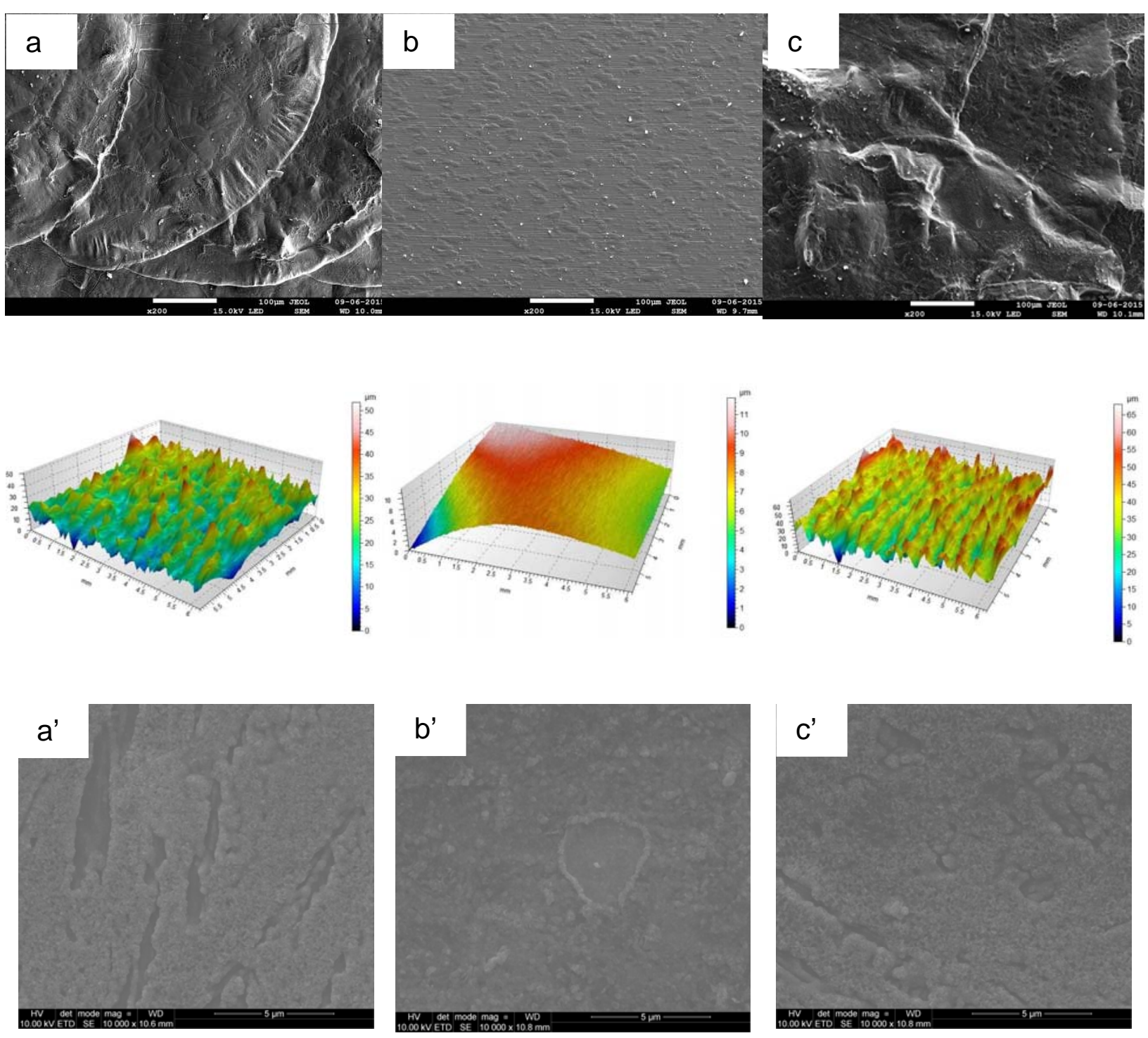

Fig. 3. Surface microstructure and topography of the Ti13Nb13Zr after laser treatment and $\mathrm{HAp}$ coating: a, a'- HC 1; b, b'- HC BM; c, c'-HC 2

Table. 3. The $R_{a}$ and $R_{z}$ parameters of Ti13Nb13Zr alloy

\begin{tabular}{|c|c|c|c|c|}
\hline \multirow{2}{*}{ Designation } & $\mathrm{R}_{\mathrm{a}}[\mu \mathrm{m}]$ & $\mathrm{R}_{\mathrm{z}}[\mu \mathrm{m}]$ & $\mathrm{R}_{\mathrm{a}}[\mu \mathrm{m}]$ & $\mathrm{R}_{\mathrm{z}}[\mu \mathrm{m}]$ \\
\cline { 2 - 5 } & \multicolumn{2}{|c|}{ after laser treatment $(\mathrm{LT})$} & \multicolumn{2}{|c|}{ after HAp deposition (HC) } \\
\hline 1 & $3.54 \pm 0.078$ & $19.21 \pm 0.110$ & $3.72 \pm 0.096$ & $24.63 \pm 0.082$ \\
\hline 2 & $4.29 \pm 0.098$ & $24.85 \pm 0.104$ & $4.82 \pm 0.087$ & $24.57 \pm 0.098$ \\
\hline $\begin{array}{c}\mathrm{BM} \\
\text { grinding and } \\
\text { polishing }\end{array}$ & $0.02 \pm 0.052$ & $0.24 \pm 0.063$ & $0.15 \pm 0.067$ & $1.02 \pm 0.048$ \\
\hline
\end{tabular}




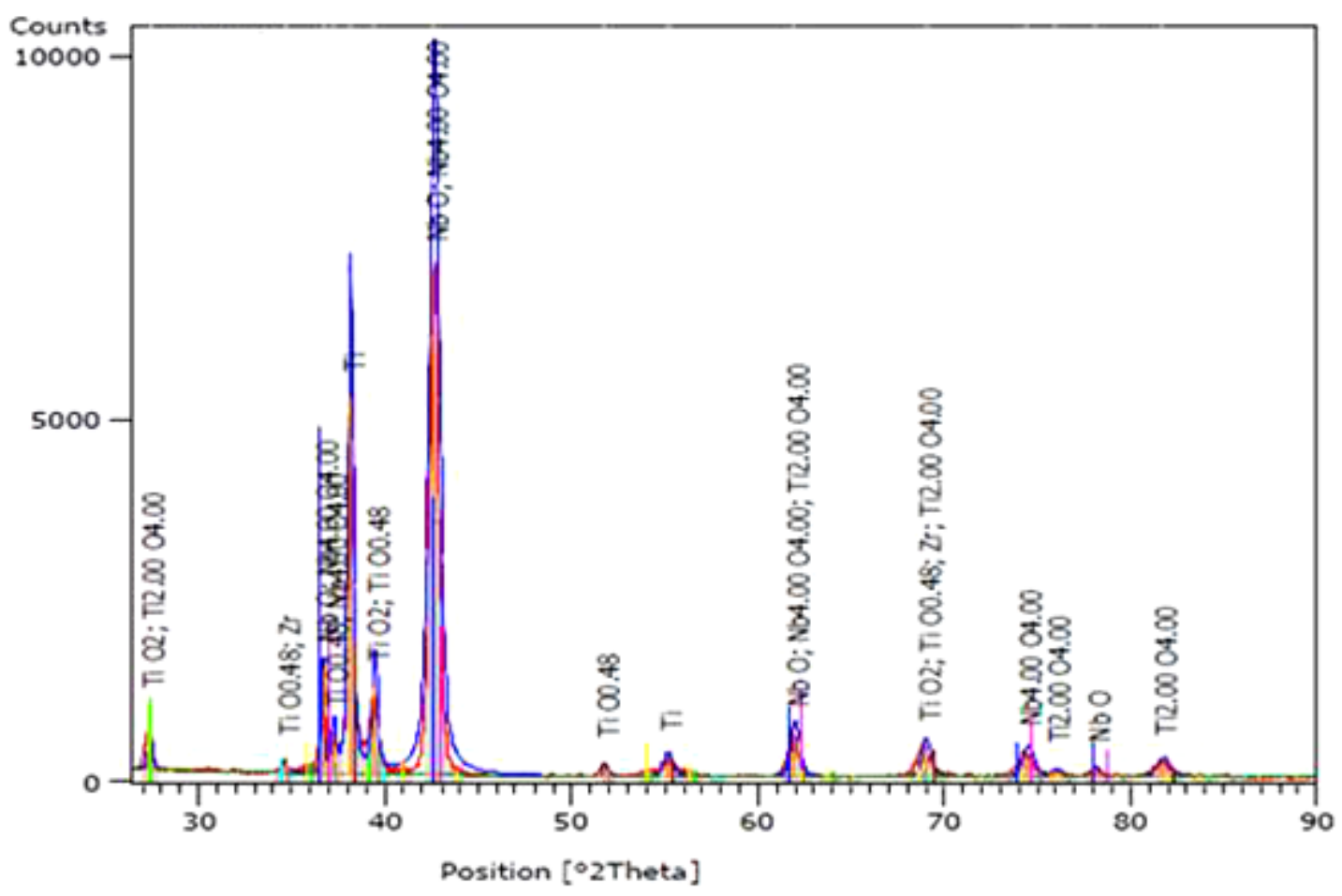

Fig. 4. XRD patterns of the Ti13Nb13Zr after laser treatment - LT 1

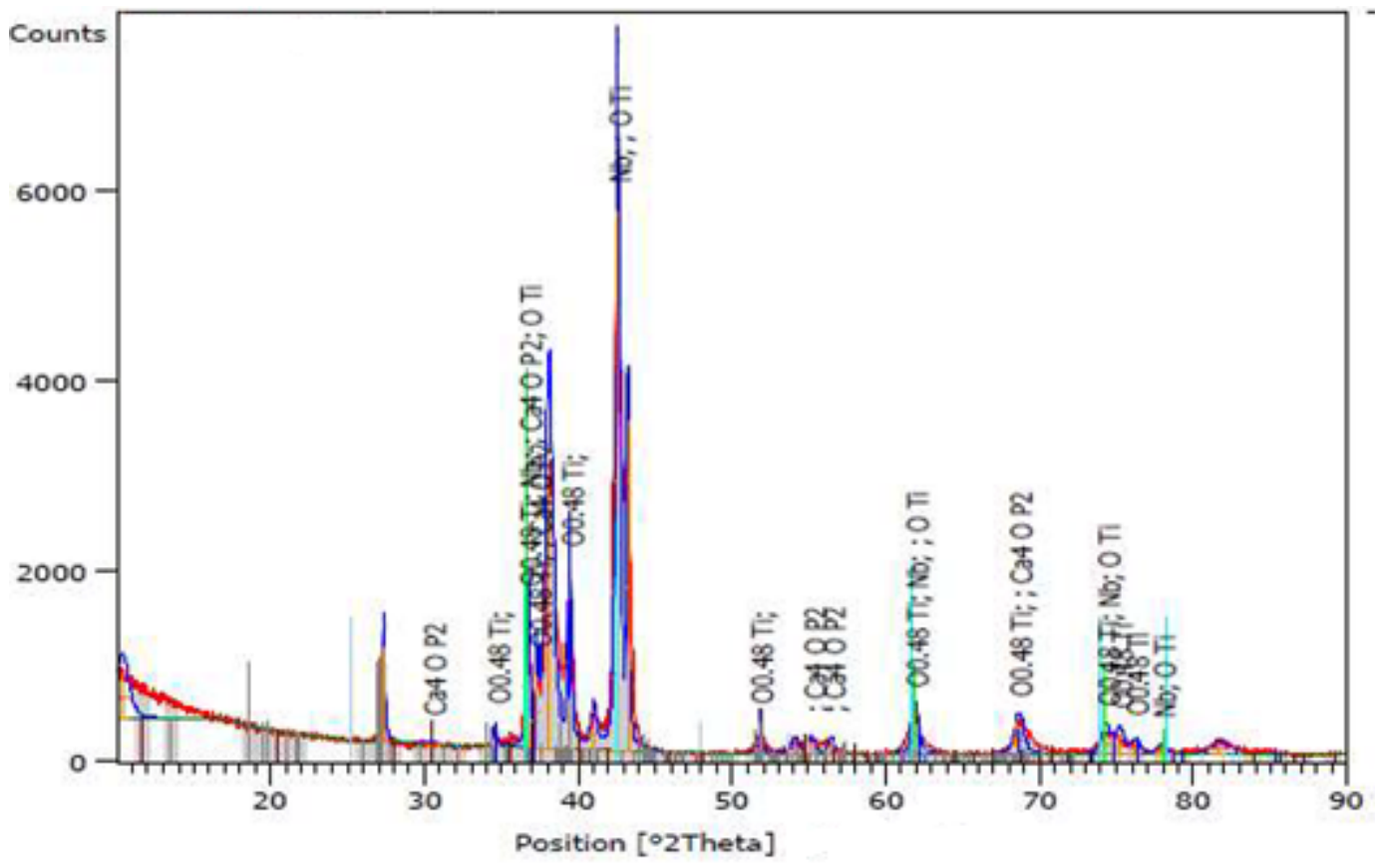

Fig. 5. XRD patterns of the Ti13Nb13Zr after laser treatment and HAp coating - HC 1

Fig. 4. demonstrates the X-ray diffraction patterns for the laser treatment the Ti13Nb13Zr alloy. The peaks of titanium oxide are characteristic for laser modified materials, especially titanium alloys. The XRD pattern for laser remelted and HAp coated surface (Fig. 5.) indicates the presence of peaks typical of hydroxyapatite and peaks characteristic of the tested alloy. 

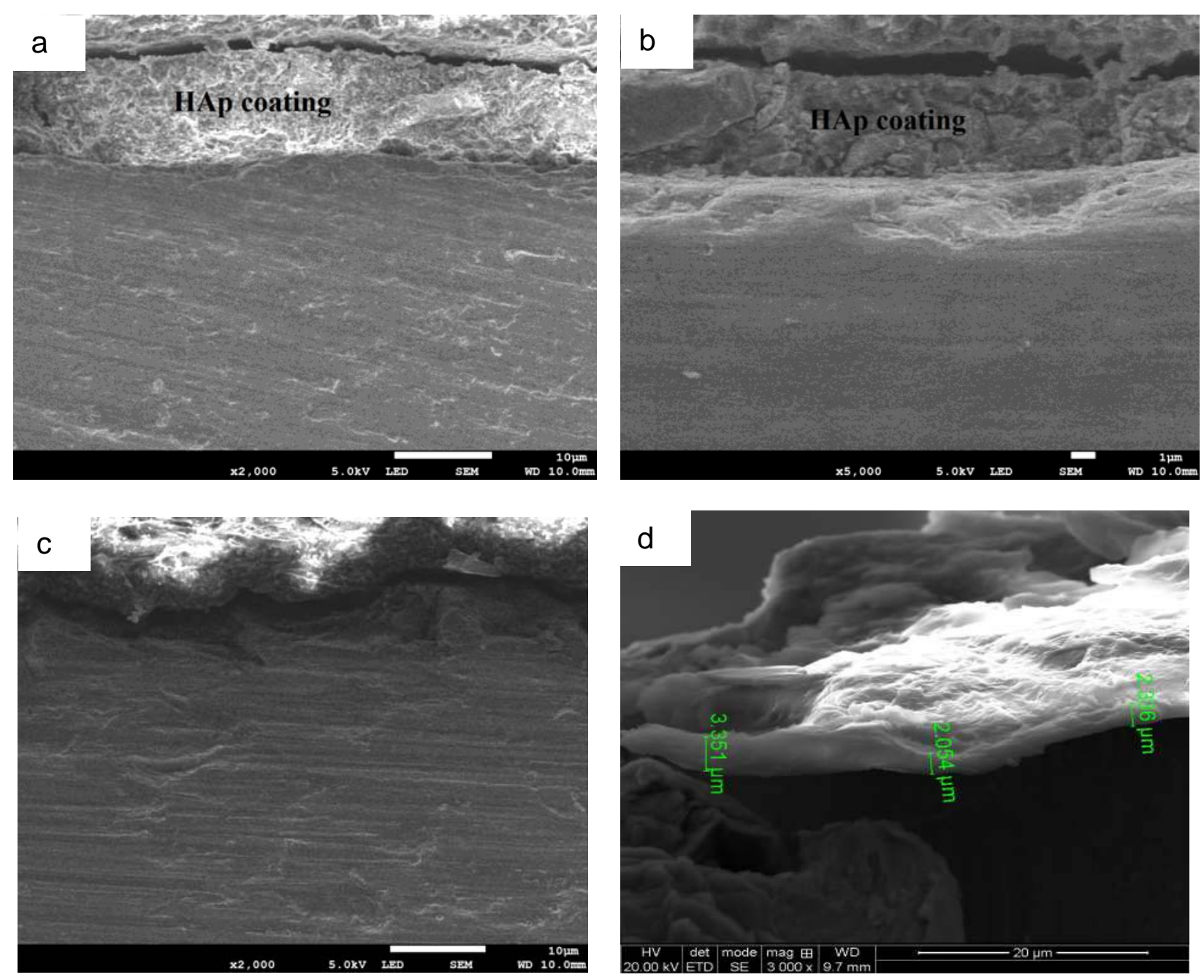

Fig. 6. The cross-section of the Ti13Nb13Zr alloy covered with HAp coating: a) $\mathrm{HC} 1$ b) HC 2, c) HC BM, d ) HC BM fracture

Fig. 6. shows the cross-section of the obtained HAp coatings on Ti13Nb13Zr alloy which give the basis for thickness measurements. The thickness of the HAp coatings was $9.05 \pm 1.05$ $\mu \mathrm{m}$ for $\mathrm{HC} 1$ and $4.06 \pm 0.76 \mu \mathrm{m}$ for HC 2 . The large standard deviation comes from the large surface roughness characteristic for the hydroxyapatite coating. The lowest thickness of the HAp coating on the base material is observed. Approximately the thickness of the HAp coating on the base material was determined in the fracture area.

\section{CONCLUSIONS}

The electrophoretic deposition of hydroxyapatite coatings on laser modified Ti13Nb13Zr alloy results in coatings of thickness from $4.06 \pm 0.76 \mu \mathrm{m}$ to $9.05 \pm 1.05$. Homogeneous, crystalline HAp coatings were obtained.

Laser treatment of Ti13Nb13Zr alloy with $\mathrm{Nd}$ :YAG laser leads to obtaining phase and morphologically modified surface layers with roughness $R_{a}$ from $3.54 \pm 0.078 \mu \mathrm{m}$ to 4.29 $\pm 0.098 \mu \mathrm{m}$. After HAp deposition roughness slighty increases. 


\section{ACNOWLEDGMENTS}

The authors thank the students - K. Bojke and M. Kierszke for their technical assistance in some tests. The helpful comments of Prof. Andrzej Zielinski are gratefully acknowledged.

\section{REFERENCES}

1. Zielinski A., Sobieszczyk S., Seramak T., Serbinski W., Swieczko-Zurek B., Ossowska A.: Biocompatibility and bioactivity of load-bearing metallic implants, Adv. Mater. Sci. 10 (2011) 21-31.

2. Wang D., Wu G., Lin X. Liu Y.: Surface coating and modification of metallic biomaterials (2015) 345-358.

3. Palanivelu R., Kalainathan S., Kumar A.: Characterization studies on plasma sprayed (AT/HA) bi-layered nanoceramics coating on biomedical commercially pure titanium dental implant, Ceram. Int. 40 (2014) 7745-7751.

4. Vasilescu C., Drob P., Vasilescu E., Demetrescu I., Ionita D., Prodana M., Drob S.: Characterization and corrosion resistance of the electrodeposited hydroxyapatite and bovine serum albumin/hydroxyapatite films on Ti-6Al- 4V-1Zr alloy surface, Corros. Sci. 53 (2011) 992-999.

5. Barry J. N., Twomey, B., Cowley, A., O'Neill, L., McNally, P.J., Dowling, D.P.: Evaluation and comparison of hydroxyapatite coatings deposited using both thermal and non-thermal techniques, Surface and Coatings Technology 226 (2013) 82 - 91.

6. Mohseni E., Zalnezhad E., Bushroa A. R.: Comparative investigation on the adhesion of hydroxyapatite coating on Ti-6Al-4V implant, International Journal of Adhesion \& Adhesives 48 (2014) $238-257$.

7. Fernandez-Pradas J.M. et all.: Characterization of calcium phosphate coatings deposited by Nd:YAG laser ablation at $355 \mathrm{~nm}$; influence of thickness, Biomaterials 23 (2002) $1989-1894$.

8. Kwok C.T. et al.: Characterization and corrosion behavior of hydroxyapatite coatings on Ti6Al4V fabricated by electrophoretic deposition, Applied Surface Science 255 (2009) 67366744.

9. Meng X., Tae-Yub Kwon T.-Y., Kim K.-H.: Hydroxyapatite coating by electrophoretic deposition at dynamic voltage, Dental Materials Journal 27(5) (2008) 666671.

10. Bartmanski M., Cieslik B., Glodowska J., Kalka P., Pawlowski L, Pieper M., Zielinski A.: Electrophoretic deposition (EPD) of nanohydroxyapatite - nanosilver coatings on Ti13Zr13Nb alloy, Ceramics International 43 (15) (2017) 11820-11829.

11. Bartmanski M., Berk A., Wojcik A.: Advances in Materials Science 16 No. 3 (49) (2016) 56 - 66.

12. Wennerberg A., Albrektson T.: Effects of titanium surface topography on bone integration: a systematic review, Clin. Oral Implants Res. 20 (4) 2009) 172 - 184.

13. Le Guéhennec L., Soueidan A., Layrolle P., Amouriq Y.: Surface treatments of titanium dental implants for rapid osseointegration. Dent. Mater. 23 (2007) 844 - 854.

14. Schuler M., Owen G.R., Hamilton D.W., de Wild M., Textor M., Brunette D.M., Tosatti S.G.: Biomimetic modification of titanium dental implant model surfaces using the RGDSP-peptide sequence: a cell morphology study, Biomaterials 27 (21) (2006) 4003 - 4015. 
15. Zieliński A., Jażdżewska M., Łubiński J., Serbiński W.: Effects of laser remelting at cryogenic conditions on microstructure and wear resistance of the Ti6Al4V alloy applied in medicine, Solid State Phenomena 183 (2012) 215 - 224.

16. Majkowska B., Jażdżewska M., Wołowiec E., Piekoszewski W., Klimek L., Zieliński A.: The possibility of use of laser-modified Ti6A14V alloy in friction pairs in endoprostheses, Archives of Metallurgy and Materials 60 (2) (2015) 755-758.

17. Oliver W.C., Pharr G.M.t: Measurement of hardness and elastic modulus by instrumented indentation: Advances in understanding and refinements to methodology, Journal of Materials Research 19 (2004) 3 - 20.

18. Feng B., Weng J., Yang B.C., Qu S.X., Zhang X.D.: Characterization of surface oxide films on titanium and adhesion of osteoblast, Biomaterials 24 (2003) 4663-4670.

19. Gross K.A., Babovic M.: Influence of abrasion on the surface characteristics of thermally sprayed hydroxyapatite coatings, Biomaterials 23 (2002) 4731-4737. 